\title{
EFFECT OF VARIETIES AND MULCH TYPES ON FOLIAR INSECT PESTS OF OKRA [Abelmoschus Esculentus L. (Moench)] IN A HUMID TROPICAL ENVIRONMENT
}

\author{
*Ojiako, F. O., Ibe, A. E., Ogu, E. C. and Okonkwo, C. C. \\ Department of Crop Science and Technology, Federal University of Technology, P.M.B.1526, \\ Owerri, Imo State, Nigeria. \\ *Corresponding Author: frankojiako@gmail.com
}

\begin{abstract}
The effect of varieties and mulch types were evaluated on some vegetative insect pests of okra (Abelmoschus esculentus) at the Federal University of Technology, Owerri, Nigeria. A $3 \times 5$ factorial in randomized complete block design (RCBD) was used to lay out the trial. Three varieties of okra (NHAe47-4, $V_{35}$ and Lady's finger) and five mulch types [dry palm fronds, dry grass, black polyethylene, groundnut (live mulch) and unmulch (as control)] were used as treatments. Ten tonnes per hectare (10 t ha-1) of dry grass and dry palm fronds, respectively, were applied before planting. The black polyethylene mulch was applied to fit the $1 \mathrm{~m} \times 3 \mathrm{~m}$ plot size. Groundnut seeds were planted between the okra plants, at a spacing of $60 \mathrm{~cm} \times 25 \mathrm{~cm}$, as live mulch. A $60 \mathrm{~cm} \times 45 \mathrm{~cm}$ spacing was used to sow the okra seeds. Data collected were plant height, number of leaves, leaf area and number of damaged leaves. At different developmental phases of the crop, insect pests were sampled. Results indicated mulch application had significant effect on insect pest leaf damage whereas no significant differences existed between the varieties used. Black polyethylene mulch treated plants had the least insect pests attack and consequently, the lowest number of damaged leaves. The flea beetle Podagrica spp., cotton leaf roller Notarcha derogata, cotton strainer Dysdercus spp., whitefly Bemisia tabaci and Nigerian grasshopper Oedaleus nigeriensis were identified as the major vegetative insect pests of okra. It may be concluded that okra cultivated with plastic mulch reduced insect pests and produced healthier plants.
\end{abstract}

Keywords: Black Polyethylene, Dry Grass, Dry Palm Fronds, Insect Pests, Live Mulch, Okra Varieties 


\section{INTRODUCTION}

Okra crop [Abelmoschus esculentus (L.) Moench], known in many English-speaking countries as lady's fingers or gumbo, is a flowering plant in the mallow family (Judd et al., 2015). The crop is a very important vegetable crop because of the area under cultivation and its consumption (Iremiren and Okiyi, 1986). Okra is distributed throughout Africa, Asia, Southern Europe, and America [Sathish et al., 2013]. Its pods, seeds, leaves, and shoots, as well as the outer cover of the flowers (calyx) are all eaten as boiled greens, blanched, fried, sautéed and steamed and is even tasty when raw, young, and fresh (NRC, 2006; Sabitha et al., 2012).The immature pods are used as boiled vegetables in slimy soups as thickener (Schippers, 2000).

Okra crop is attacked by numerous insect pests from seedling to the stage of harvest (Kedar et al, 2014). The shoot and fruit borer (Earias vittella), the flea beetle (Podagrica uniforma and $P$. sjostedti), whitefly (Bemisia tabaci), leafhopper (Amrascabiguttula biguttula), dusky cotton bug (Oxycarenus hyalinipennis), fruit borer (Helicoverpa armigera), leaf roller (Sylepta derogata), aphid (Aphis gossypii), solenopsis mealy bug (Phenacoccus solenopsis), red cotton bug (Dysdercus koenigii), red spider mite (Tetranychus urticae), etc., are some of the more important ones. In West Africa, most damage to okra is, however, inflicted by the two flea beetle species, Podagrica uniforma and $P$. sjostedti which are responsible for heavy defoliation (Odebiyi, 1980) and important yield losses in Nigeria, Ghana and Burkina Faso (Obeng-Ofori and Sackey, 2003; Ahmed et al., 2007; Dabiré-Binsoet al. 2009). Podagrica species transmit the okra mosaic virus, causing significant fruit yield reduction of about $18-50 \%$ (Vanlommel et al, 1996; Alegbejo et al., 2008; Pitan and Ekojab, 2011). The insects have been observed to commence their infestation on Okra plants from the stage of germination and throughout all stages of its growth.

Numerous cultural measures have been adopted to curtail the problems associated with insect infestation on crops, including the use of mulches. Mulching, which can be described as covering of the top soil with a protective material, is one of the most beneficial and simplest agronomic practices for reducing erosion, suppressing weed growth, retaining water and enhancing pest and disease protection in gardens (Mugalla et al., 1996; Iqbal,et al., 2009).

Mochiah et al. (2012) reported that cowpea live mulch can effectively suppress pest populations in pepper while the use of groundnut as live mulch in an intercropping system have been recommended (Ibeawuchi et al., 2005). Grass (Pennisetum) mulch has been effectively used to control weeds, reduce soil temperature and conserve soil moisture (Awodoyin et al., 2007). Staking tomato crops and mulching the soil surface with either black polyethylene films or grass under wet conditions has been reported to significantly increase marketable yield (Babatola and 
Olaniyi, 1999). Contrarily, relatively high pest populations have been reported in plots mulched with straw when compared with other treatments (Johnson et al., 2004)

Polyethylene mulch has been found to improve retention of soil moisture, reduce rot in crown fruit, inhibit weed growth, increase yield delay tomato yellow leaf curl (TYLC) by at least 14 days, ameliorate tomato spotted wilt (TSW) significantly, stem soil nutrient leaching and effectively control pests (Gilreath, 2001; Kwabiah, 2004; Ban et al., 2009; Berihun, 2011; Hatami et al., 2012, Mahadeen, 2014).

Most of the experiments on mulching materials were primarily to determine their effect in soil water conservation, reduction of salt accumulation in the soil, soil temperature amelioration, weed suppression and the resultant effect on crop yield (Jamil et al., 2005; Awodoyin et al., 2007; AlRawahy et al., 2011; Mochiah et al., 2012)

Studies conducted to ascertain the comparative effect of the five mulch types: dry palm fronds, dry grass, black polyethylene, groundnut (live mulch) and unmulch (as control) to control insect pests of okra in a humid tropical environment, is relatively novel in our clime.

This study, therefore, was aimed at determining the types of insect pests that attack okra in Owerri area of Imo State, their preponderance, extent of damage caused and effect of the mulch types in their control.

\section{MATERIALS AND METHODS}

\section{Experiment Site}

The trials were performed at the Demonstration Farm of the School of Agriculture and Agricultural Technology, Federal University of Technology, Owerri, southeastern Nigeria, which lies between latitudes $44^{\circ} 40^{1} \mathrm{~N}$ and $8^{\circ} 15^{1} \mathrm{~N}$, longitudes $6^{\circ} 40^{1}$ and $8^{\circ} 30^{1} \mathrm{E}$. Soils of the area are derived from vast parent materials including Bende-Ameki Shale, Coastal plain sand, false bedded sandstone, Alluvium, Lower coal measure and Upper coal measure (Ahukaemere et al., 2016). The site which lies at the tropical rain forest zone has two climatic seasons - the rainy season which commences at about April and exits in October and dry season (from mid-November to March of the succeeding year). The average rainfall is about $2,134 \mathrm{~mm}$ while daily temperature ranges from $21^{\circ} \mathrm{C}$ to $34^{\circ} \mathrm{C}$ (NIMET, 2012). The relative humidity reaches a minimum of $60 \%$ in January (at the peak of the dry season) and rises to $70-85 \%$ in July (at the peak of the rains).

\section{Field preparation and procurement of planting materials}

The existing secondary vegetation was cleaned with cutlasses and the debris raked from the site. A $29 \mathrm{~m} \times 11 \mathrm{~m}\left(319 \mathrm{~m}^{2}\right)$ area was measured out with a tape, rope and pegs. 
Three varieties of okra were used for the trial: NHAe47-4, $\mathrm{V}_{35}$ and Lady's finger. The NHAe47-4 seeds, bred by and sourced from the National Horticultural Research Institute (NIHORT) Ibadan, Nigeria, is early flowering, has thick fresh pods, is short to medium in height with deeply lobed leaves and branches profusely (NIHORT, 1986). $V_{35}$ seeds, an adapted exotic variety with almost the same morphological features as the NHAe47-4, was also obtained from NIHORT. Seeds of Lady's finger, an elite variety that is well-liked by the people of southeastern Nigeria, were collected from Imo State Agricultural Development Project (ADP), Owerri, Nigeria. It is early flowering, medium in height with nearly entire leaf margin and branches diagonally upwards at an angle of $45^{\circ}$ with the main stem (lyagba et al., 2012).

The black polyethylene mulch material was bought from Ekeonunwa Market in Owerri, Imo State while other mulching materials were sourced within the experimental site.

\section{Experimental Design and Treatment Combinations}

The experiment was laid out as a $3 \times 5$ factorial in a randomized complete block design (RCBD). This was replicated three times with each plot measuring $1 \mathrm{~m} \times 3 \mathrm{~m}$. Between the plots and blocks were $1 \mathrm{~m}$ alleys. This gave a total of 45 plots with 24 plants per plot at $60 \mathrm{~cm} \times 45 \mathrm{~cm}$ spacing.

Groundnut (live mulch); Dry grass at 10 tonnes/ha or $16 \mathrm{~kg} / \mathrm{plot;}$ Dry Palm frond at 10 tonnes/ha or $16 \mathrm{~kg} / \mathrm{plot}$; Black polythene mulch and Unmulch (control) were the five mulching materials tested with the three different varieties of okra.

These five mulching materials (including unmulch), were randomly allocated into blocks with the three varieties of okra. These gave a total of 15 treatment combinations viz: $V_{1}=$ NHAe47-4; $V_{2}=$ $V_{35}$ and $V_{3}=$ Lady's Finger; $A_{1}=$ Groundnut (live mulch), $A_{2}=$ Dry grass, $A_{3}=$ Black polythene, $A_{4}$ $=$ Dry Palm frond and $A_{5}=$ Unmulch.

\section{Field Application of Treatment/sowing}

Measured mulch materials were applied in each of the plots according to their treatments a day before planting. Ten tones (10 t) of dry grass and dry palm frond were applied before planting, while black polythene was cut to size the $1 \mathrm{~m} \times 3 \mathrm{~m}$ plot. Groundnut, planted at a spacing of 60 $\mathrm{cm} \times 25 \mathrm{~cm}$ between the okra plants, was used as live mulch. Two okra seeds were planted per hole at a spacing of $60 \mathrm{~cm} \times 45 \mathrm{~cm}$ and later thinned down to one.

Weeds were removed manually at 3 weeks after planting and subsequently every 2 weeks with hoe. 


\section{Data Collection}

Leaf area: Data collected from five (5) randomly selected plants involved measuring the length and width of the leaf and multiplying it with factors 0.89 for NHAC $47-4$ and 0.56 for V35 and Lady's Finger. This was done at 2, 4 and 6 weeks after planting (WAP), respectively.

Plant height: Collected from five (5) randomly selected plants. Measurements were obtained from the ground level to the top of the plants using a meter rule. This was done at 2, 4 and 6 WAP, respectively.

Number of leaves per plant: Physical enumeration of leaves from the 5 randomly selected plants was recorded at 2,4 and 6 WAP, respectively.

Number of leaves damaged by insects: The visual recording of the number of leaves damaged by insects was done by counting these leaves on the 5 randomly selected and tagged stands. These were recorded at 2, 4 and 6 WAP, respectively.

Sampling of insect pests: Sweep net, sample bottles and cellophane bags were used to collect the insect pests. Other non motile insects were hand-picked with plastic forceps and hand gloves. Samplings were done early in the morning (from 6:30 am -7:30 am) on Saturdays at 2, 3, 4, 5 and 6 WAP, respectively. Insects collected were stored in transparent containers with cotton wool dipped in chloroform. The insects were later identified in the laboratory and recorded.

Analysis of Data: Analysis of Variance (ANOVA) for Randomized Complete Block Design $(\mathrm{RCBD})$ in a $3 \times 5$ factorial arrangement was used to analyze collated data. GENSAT Computer Software was employed and means separated as prescribed by Wahua (1999). Fisher's Least Significant Difference (LSD) at $\mathrm{P}=0.05$ level of significance was used.

\section{RESULTS}

Variety and mulch had significant effect on the number of leaves of okra as shown in Table 1. Though variety alone had significant effect at 4 WAP only, the interaction between variety and mulch had no significant effect at 2, 4 and 6 WAP. However, mulching, had significant effect on the number of leaves of okra throughout the duration of the experiment $(P=0.05)$. Of the mulch types, black plastic mulch had the highest effect at 2, 4 and 6 WAP $(6.42,19.69$ and 17.81 leaves, respectively), followed by dry grass, palm frond, unmulch and live mulch (groundnut) in that order. At 4 WAP, the number of leaves were significantly influenced by variety with $V_{35}$ scoring the highest (17.68), followed by Lady's finger (17.51) and NHAe47-4 (14.36), respectively. 
The effect of variety and mulch on okra plant leaf area at 2, 4 and 6 WAP is presented in Table 2. There were no interaction effects between variety and mulch types during the period under review. Variety alone had significant effect $(p=0.05)$ on leaf area at 2 and 6 WAP: NHAe47-4 $\left(34.40 \mathrm{~cm}^{2}\right.$ and $\left.236.20 \mathrm{~cm}^{2}\right), V_{35}\left(27.50 \mathrm{~cm}^{2}\right.$ and $\left.179.20 \mathrm{~cm}^{2}\right)$ and Lady's finger $\left(26.00 \mathrm{~cm}^{2}\right.$ and $\left.159.4 \mathrm{~cm}^{2}\right)$ for 2 and 6 WAP, respectively. Mulch types had significant effect only at 2 WAP with dry grass having the highest mean value $\left(35.60 \mathrm{~cm}^{2}\right)$ followed by black plastic $\left(34.10 \mathrm{~cm}^{2}\right)$, palm frond $\left(32.50 \mathrm{~cm}^{2}\right)$, unmulch $\left(23.90 \mathrm{~cm}^{2}\right)$ and groundnut life mulch $\left(20.30 \mathrm{~cm}^{2}\right)$, respectively.

Mulching had statistically significant effect $(p=0.05)$ on plant height at 2, 4 and 6 WAP (Table 3). At 2 WAP, palm frond mulch recorded the highest plant height $(10.78 \mathrm{~cm})$ followed by dry grass $(9.34 \mathrm{~cm})$, black plastic $(8.94 \mathrm{~cm})$, life mulch $(7.47 \mathrm{~cm})$ and unmulch $(7.41 \mathrm{~cm})$ in that order. At 4 WAP, the highest height came from plants mulched with black plastic $(35.63 \mathrm{~cm})$, followed by dry grass $(35.56 \mathrm{~cm})$, palm bunch $(35.14 \mathrm{~cm})$, unmulch $(32.50 \mathrm{~cm})$ and life mulch $(28.06 \mathrm{~cm})$ in that order. By the $6^{\text {th }}$ week, palm bunch had the highest mean value of $78.91 \mathrm{~cm}$ followed by unmulch, plastic, dry and live mulch with $78.60,65.93,63.49$ and $50.96 \mathrm{~cm}$, respectively. The different varieties had no statistical effect at 2 WAP but had significant effect at 4 and 6 WAP with NHAe47-4 having the highest mean value $(40.26 \mathrm{~cm}$ and $90.12 \mathrm{~cm})$ followed by $\mathrm{V}_{35}(32.49$ and $57.38 \mathrm{~cm}$ ) and Lady's finger $(27.38$ and $55.23 \mathrm{~cm}$ ), respectively. Only at 6 WAP did the interaction between variety and mulch type have significant effect.

Table 4 shows the effect of variety and mulch type on the number of damaged leaves at 2, 4 and 6 WAP. Though variety had no significant effect on damaged leaves at 2, 4 and 6 WAP, mulching had. Plants treated with palm bunch had the highest number of damaged leaves (1.62) followed by dry grass, life mulch and unmulch $(1.58,1.51$ and 1.44$)$ leaves, respectively. Plastic covered plots had the least number of damaged leaves (1.11). Interaction effect between mulch type and variety had significant effect at 2 and 4 WAP only.

Presented in Table 5 is the influence of variety and mulch type on the abundance of cotton strainer (Dysdercus spp.) at 2, 3, 4, 5 and 6 WAP. The mean number of the insect (at 2, 3, 4 and 6 WAP) is least in Lady's finger $\left(3.00,2.20,2.60\right.$ and 2.60, respectively). NHAe47-4 and $V_{35}$ were not consistent. On the effect of mulching materials, plastic mulch had significant effect $(P=0.05)$ and had consistently the lowest mean number of insects throughout the duration of the trial $(1,78$, $1.14,1.56,1.78$ and 2.33 insects, respectively), whereas plants mulched with palm frond mulch (at 2, 3, 5 and 6 WAP, respectively) recorded the highest mean number of insects. Groundnut live mulch and grass mulch significantly performed better than the control (unmulch).

Table 6 depicts the effect of variety and mulch on the population of Bemisia tabaci (Gennadius, 1889 ) at 2, 3, 4, 5 and 6 WAP. Variety did not significantly affect $B$. tabaci infestation, however, 
mulch materials had significant effects $(P=0.05)$ at 2, 3, 5 and 6 WAP. Plastic mulch, again, recorded the least mean number of the insect: 2 WAP (1.44), 3 WAP (1.44), 4 WAP (1.56), 5 WAP (1.44) and 6 WAP (1.56) while other materials neither showed any consistent pattern nor did they have clear differences between them and the control.

Presented in Table 7 is the effect of variety and mulch types on the preponderance of the leaf roller Notarcha derogata (Fabricius, 1775) at 2,3,4,5, and 6 WAP. Results showed that the interaction of variety and mulch had no significant effect $(P=0.05)$ on the incidence of $N$. derogata throughout the duration of the experiment. Only at 2 and 3 WAP did mulch materials have any significant effect with groundnut (live) mulch having the least number of $N$. derogata at 2, 3, 4 and $6 \operatorname{WAP}(5.70,5.78,6.40$. and 6.90 insects, respectively) followed closely by black plastic mulch $(8.00,7.56,8.60,6.33$ and 7.7 insects) for $2,3,4,5$, and 6 WAP, respectively. With the exception at 3 WAP, variety alone had no significant effect on $N$. derogata infestation.

Table 8 depicts the effect of variety and mulch on Oedaleus nigeriensis (Uvarov, 1926) at 2, 3, 4, 5 and 6 WAP. Variety alone recorded no significant effect at 2 and 4 WAP but significantly $(P=$ 0.05 ) influenced 0 . nigeriensis presence at 3,5 and 6 WAP. Throughout the duration of the experiment, mulching had significant effect on the abundance of 0 . nigeriensis. The least mean number of the insects throughout the duration of the study $(1.56,3.00,1.78,2.22$ and 2.00 insects) was recorded with black plastic mulch at 2, 3, 4, 5 and 6 WAP, respectively. Dry grass mulch treated plants had the highest grand mean (6.56 insects) for the 6 weeks under review. Interaction analysis indicated that variety and mulch had significant effect $(P=0.05)$, throughout the 6 weeks of the experiment, on the number of the insects.

The effect of variety and mulch type on the number of Podagrica spp. at 2, 3, 4, 5 and 6 WAP is shown in Table 9. The analysis of variance showed that interaction of variety and mulch and variety alone did not significantly influence the abundance of Podagrica at 2, 3, 4, 5 and 6 WAP. Mulch materials had significant effect at 2, 4, 5 and 6 WAP only. Plastic mulched plants had the least number of Podagrica at 2, 5 and 6 WAP while unmulch (control) had the highest mean value. 
Table 1: Effect of Varieties and Mulch Types on Number of Leaves of Abelmoschus esculentus at 2, 4 and 6 WAP

\begin{tabular}{|c|c|c|c|c|c|c|c|c|c|c|c|c|}
\hline \multirow[b]{2}{*}{ Mulch } & \multirow[b]{2}{*}{ Lady F } & \multicolumn{2}{|l|}{2 WAP } & \multirow[b]{2}{*}{ Mean } & \multicolumn{4}{|c|}{4 WAP } & \multicolumn{4}{|c|}{6 WAP } \\
\hline & & NHAe47-4 & $V_{35}$ & & Lady F & NHAe47-4 & $\mathrm{V}_{35}$ & Mean & Lady F & NHAe47-4 & $V_{35}$ & Mean \\
\hline Grass & 6.67 & 6.20 & 6.40 & 6.32 & 20.40 & 16.21 & 18.73 & 18.45 & 18.77 & 14.93 & 17.50 & 17.07 \\
\hline G/N & 5.73 & 5.40 & 5.53 & 5.56 & 12.20 & 10.33 & 12.83 & 11.79 & 10.63 & 10.67 & 11.30 & 10.87 \\
\hline Palm & 5.73 & 5.93 & 6.40 & 6.02 & 17.94 & 14.33 & 18.13 & 16.80 & 16.20 & 12.87 & 16.07 & 15.04 \\
\hline Plastic & 6.33 & 6.40 & 6.20 & 6.42 & 22.40 & 14.93 & 21.73 & 19.69 & 18.53 & 14.37 & 20.53 & 17.81 \\
\hline UM & 5.93 & 5.87 & 5.73 & 5.84 & 14.63 & 16.01 & 16.95 & 15.86 & 13.87 & 14.57 & 14.97 & 14.47 \\
\hline Mean & 6.080 & 5.960 & 6.053 & & 17.51 & 14.36 & 17.68 & & 15.60 & 13.48 & 16.07 & \\
\hline \multicolumn{2}{|c|}{ LSD (Variety) } & \multicolumn{2}{|l|}{ NS } & \multicolumn{2}{|r|}{2.530} & & \multicolumn{2}{|c|}{ NS } & & & & \\
\hline \multicolumn{2}{|c|}{ LSD (Mulch) } & \multicolumn{2}{|l|}{0.4371} & \multicolumn{2}{|r|}{ 3. 266} & & \multicolumn{2}{|c|}{2.876} & & & & \\
\hline \multicolumn{4}{|c|}{ LSD (Variety x Mulch) NS } & \multicolumn{2}{|r|}{ NS } & & \multicolumn{2}{|c|}{ NS } & & & & \\
\hline
\end{tabular}

Grass = Dry grass; G/N = Groundnut (live mulch); Palm = Dry palm frond; Plastic = Black polythene; UM = Unmulch. LSD = Least Significant Difference; NS = Not Significant; WAP = Weeks after Planting 
Table 2: Effect of Varieties and Mulch Types on the Leaf Area $\left(\mathrm{cm}^{2}\right)$ of Abelmoschus esculentus at 2, 4, and 6 WAP

\begin{tabular}{|c|c|c|c|c|c|c|c|c|c|c|c|c|}
\hline \multirow[b]{2}{*}{ Mulch } & \multirow[b]{2}{*}{ Lady F } & \multicolumn{3}{|c|}{2 WAP } & \multicolumn{4}{|c|}{4 WAP } & \multicolumn{4}{|c|}{6 WAP } \\
\hline & & NHAe47-4 & $V_{35}$ & Mean & Lady F & NHAe47-4 & $V_{35}$ & Mean & Lady F & NHAe47-4 & $V_{35}$ & Mean \\
\hline Grass & 28.00 & 44.80 & 34.10 & 35.60 & 261.00 & 385.00 & 957.00 & 534. & 207.50 & 235.00 & 191.00 & 211.10 \\
\hline G/N & 22.80 & 20.90 & 17.10 & 20.30 & 177.00 & 231.00 & 160.00 & 189. & 128.80 & 216.00 & 137.50 & 160.80 \\
\hline Palm & 25.50 & 37.60 & 34.40 & 32.50 & 192.00 & 263.00 & 247.00 & 234 & 123.90 & 212.60 & 183.50 & 173.30 \\
\hline Plastic & 32.10 & 38.70 & 31.60 & 34.10 & 272.00 & 298.00 & 296.00 & 288 & 198.60 & 271.30 & 204.70 & 224.90 \\
\hline UM & 21.50 & 29.90 & 20.20 & 23.90 & 188.00 & 228.00 & 209.00 & 269 & 138.20 & 245.90 & 179.20 & 187.80 \\
\hline Mean & 26.00 & 34.40 & 27.50 & & 218.00 & 281.00 & 374.00 & & 159.4 & 236.20 & 179.20 & \\
\hline \multicolumn{2}{|c|}{ LSD (Variety) } & \multicolumn{2}{|l|}{6.26} & \multicolumn{2}{|l|}{ NS } & \multicolumn{3}{|c|}{36.70} & & & & \\
\hline \multicolumn{2}{|c|}{ LSD (Mulch) } & \multicolumn{2}{|l|}{8.08} & \multicolumn{2}{|c|}{ NS } & \multicolumn{3}{|r|}{ NS } & & & & \\
\hline \multicolumn{2}{|c|}{ LSD (Variety x Mulch) } & \multicolumn{2}{|l|}{ NS } & \multicolumn{2}{|c|}{ NS } & \multicolumn{3}{|r|}{ NS } & & & & \\
\hline
\end{tabular}

Grass $=$ Dry grass; $\mathrm{G} / \mathrm{N}=$ Groundnut (live mulch); Palm $=$ Dry palm frond; Plastic $=$ Black polythene; $\mathrm{UM}=$ Unmulch .

LSD = Least Significant Difference; NS = Not Significant; WAP = Weeks after Planting 
Table 3: Effect of Varieties and Mulch Types on Plant Height (cm) of Abelmoschus esculentus at 2, 4 and 6 WAP

\begin{tabular}{|c|c|c|c|c|c|c|c|c|c|c|c|c|}
\hline \multirow[b]{2}{*}{ Mulch } & \multirow[b]{2}{*}{ Lady F } & \multicolumn{3}{|c|}{2 WAP } & \multicolumn{4}{|c|}{4 WAP } & \multicolumn{4}{|c|}{6 WAP } \\
\hline & & NHAe47-4 & $V_{35}$ & Mean & Lady F & NHAe47-4 & $V_{35}$ & Mean & Lady F & NHAe47-4 & $V_{35}$ & Mean \\
\hline Grass & 9.40 & 9.37 & 9.24 & 9.34 & 27.64 & 45.51 & 33.52 & 35.56 & 50.47 & 88.06 & 51.94 & 63.49 \\
\hline G/N & 8.13 & 7.13 & 7.13 & 7.47 & 24.13 & 32.60 & 27.46 & 28.06 & 52.78 & 59.15 & 40.93 & 50.96 \\
\hline Palm & 11.23 & 9.73 & 11.39 & 10.78 & 30.35 & 42.13 & 32.95 & 35.14 & 60.89 & 112.11 & 63.74 & 78.91 \\
\hline Plastic & 9.03 & 8.90 & 8.90 & 8.94 & 27.87 & 42.85 & 36.17 & 35.63 & 43.84 & 100.84 & 53.10 & 65.93 \\
\hline UM & 8.25 & 6.58 & 7.40 & 7.41 & 26.93 & 38.19 & 32.38 & 32.50 & 68.16 & 90.42 & 77.21 & 78.60 \\
\hline Mean & 9.21 & 8.34 & 8.81 & & 27.38 & 40.26 & 32.49 & & 55.23 & 90.12 & 57.38 & \\
\hline \multicolumn{2}{|c|}{ LSD (Variety) } & \multicolumn{2}{|l|}{ NS } & \multicolumn{2}{|c|}{3.506} & & \multicolumn{2}{|c|}{3.010} & & & & \\
\hline \multicolumn{2}{|c|}{ LSD (Mulch) } & \multicolumn{2}{|l|}{1.355} & \multicolumn{2}{|r|}{4.527} & & \multicolumn{2}{|r|}{4.004} & & & & \\
\hline \multicolumn{2}{|c|}{ LSD (Variety x Mulch) } & \multicolumn{2}{|l|}{ NS } & \multicolumn{2}{|r|}{ NS } & & \multicolumn{2}{|r|}{6.935} & & & & \\
\hline
\end{tabular}

Grass = Dry grass; G/N = Groundnut (live mulch); Palm = Dry palm frond; Plastic = Black polythene; UM = Unmulch. LSD = Least Significant Difference; NS = Not Significant; WAP = Weeks after Planting

Table 4: Effect of Varieties and Mulch Types on Number of Damaged Leaves of Abelmoschus esculentus at 2, 4 and 6 WAP

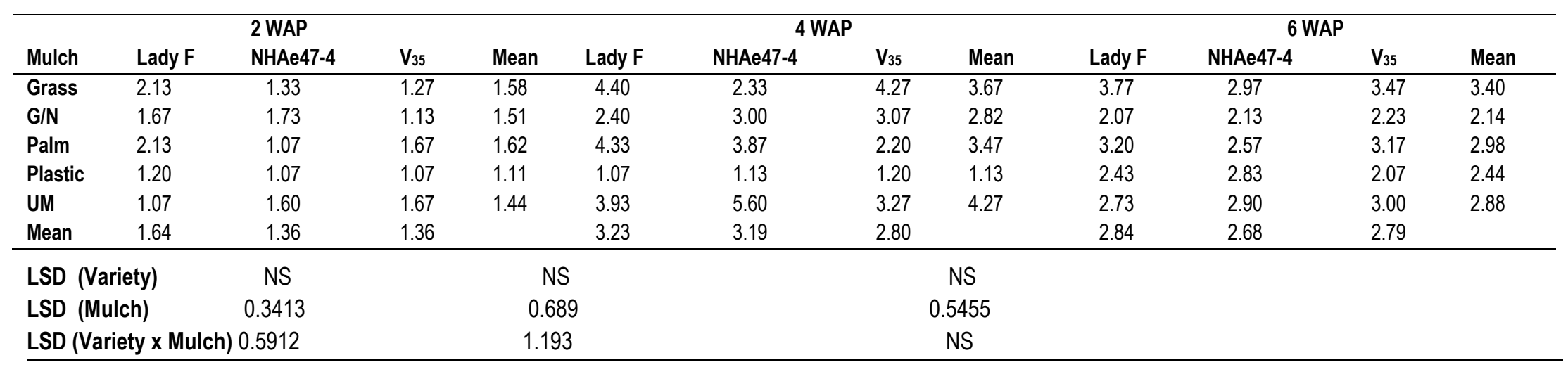

Grass = Dry grass; G/N = Groundnut (live mulch); Palm = Dry palm frond; Plastic = Black polythene; UM = Unmulch. LSD = Least Significant Difference; NS = Not Significant; WAP = Weeks after Planting 
Table 5: Effect of Varieties and Mulch Types on Cotton Strainer (Dysdercus spp.) at 2, 3, 4, 5 and 6 WAP

\begin{tabular}{|c|c|c|c|c|c|c|c|c|c|c|c|c|c|c|c|c|c|c|c|c|}
\hline & \multicolumn{5}{|c|}{2 WAP } & \multicolumn{2}{|c|}{3 WAP } & \multicolumn{5}{|c|}{4 WAP } & \multicolumn{3}{|c|}{5 WAP } & \multicolumn{5}{|c|}{6 WAP } \\
\hline Mulch & Lady F & NHAe47- & $V_{35}$ & Mean & Lady F & NHAe47-4 & $V_{35}$ & Mean & Lady F & NHAe47- & $\mathbf{V}_{35}$ & Mean & Lady F & NHAe47- & $\mathbf{V}_{35}$ & Mean & Lady $F$ & NHAe47- & $\mathbf{V}_{35}$ & Mean \\
\hline Grass & 2.67 & 4.33 & 3.30 & 3.33 & 2.00 & 3.33 & 3.00 & 2.78 & 4.00 & 3.00 & 4.00 & 3.78 & 1.33 & 1.33 & 2.33 & 1.67 & 3.00 & 4.67 & 5.33 & 4.33 \\
\hline G/N & 3.00 & 2.33 & 3.67 & 3.00 & 2.33 & 2.67 & 2.33 & 2.44 & 2.00 & 2.67 & 2.33 & 2.33 & 2.00 & 3.00 & 2.67 & 2.56 & 2.33 & 2.33 & 3.33 & 2.67 \\
\hline Palm & 4.67 & 7.00 & 5.33 & 5.67 & 3.67 & 3.33 & 6.00 & 4.33 & 2.67 & 5.00 & 2.67 & 3.44 & 3.33 & 1.33 & 3.00 & 2.56 & 2.67 & 7.67 & 6.00 & 5.44 \\
\hline Plastic & 2.00 & 1.67 & 1.67 & 1.78 & 1.00 & 1.33 & 2.00 & 1.14 & 1.67 & 1.67 & 1.33 & 1.56 & 2.00 & 1.33 & 2.00 & 1.78 & 1.67 & 3.33 & 2.00 & 2.33 \\
\hline Um & 2.67 & 6.67 & 2.67 & 4.00 & 1 & 4.00 & 4.67 & 356 & 2.67 & 2.67 & 4.33 & 3.22 & 2.00 & 1.67 & 3.67 & 2.44 & 3.33 & 5.00 & 6.67 & 5.00 \\
\hline \multirow[t]{4}{*}{ Mean } & 3.00 & 4.40 & 3.27 & & 2.20 & 2.93 & 3.60 & & 2.60 & 3.07 & 2.93 & & 2.13 & 1.73 & 2.73 & & 2.60 & 4.60 & 4.67 & \\
\hline & \multicolumn{3}{|c|}{ LSD (Variety) } & \multicolumn{2}{|c|}{0.939} & \multicolumn{2}{|c|}{0.715} & \multicolumn{2}{|c|}{ NS } & \multicolumn{3}{|c|}{0.551} & \multicolumn{3}{|c|}{0.796} & & & & & \\
\hline & \multicolumn{3}{|c|}{ LSD (Mulch) } & \multicolumn{2}{|c|}{1.212} & \multicolumn{2}{|c|}{0.923} & \multicolumn{2}{|c|}{0.827} & \multicolumn{3}{|c|}{0.711} & \multicolumn{3}{|c|}{1.779} & & & & & \\
\hline & \multicolumn{3}{|c|}{ LSD (Variety x Mulch } & h) 2.0 & & \multicolumn{2}{|c|}{ NS } & \multicolumn{2}{|c|}{1.432} & \multicolumn{3}{|c|}{1.234} & & 1.779 & & & & & & \\
\hline
\end{tabular}

Grass $=$ Dry grass; $\mathrm{G} / \mathrm{N}=$ Groundnut (live mulch); Palm $=$ Dry palm frond; Plastic $=$ Black polythene; $\mathrm{UM}=$ Unmulch.

LSD = Least Significant Difference; NS = Not Significant; WAP = Weeks after Planting

Table 6: Effect of Varieties and Mulch Types on Whitefly (Bemisia tabaci) at 2, 3, 4, 5 and 6 WAP

\begin{tabular}{|c|c|c|c|c|c|c|c|c|c|c|c|c|c|c|c|c|c|c|c|c|}
\hline & \multicolumn{5}{|c|}{2 WAP } & \multicolumn{2}{|c|}{3 WAP } & \multicolumn{5}{|c|}{4 WAP } & \multicolumn{3}{|c|}{5 WAP } & \multicolumn{5}{|c|}{6 WAP } \\
\hline Mulch & Lady F & NHAe47- & V 35 & Mean & Lady $F$ & NHAe47-4 & V 35 & Mean & Lady F & NHAe47- & V 35 & Mean & Lady F & NHAe47- & V 35 & Mean & Lady F & NHAe47- & V 35 & Mean \\
\hline Grass & 3.00 & 3.33 & 2.67 & 3.00 & 2.00 & 3.00 & 2.33 & 2.44 & 2.33 & 2.00 & 3.00 & 2.44 & 2.67 & 3.33 & 3.00 & 3.00 & 2.67 & 2.67 & 4.67 & 3.33 \\
\hline G/N & 2.00 & 3.33 & 1.67 & 2.33 & 2.67 & 3.33 & 4.00 & 3.33 & 2.33 & 2.67 & 3.33 & 2.78 & 3.67 & 1.33 & 2.33 & 2.44 & 3.33 & 2.67 & 3.00 & 3.00 \\
\hline Palm & 2.67 & 4.00 & 2.00 & 2.89 & 3.33 & 2.67 & 1.67 & 2.56 & 3.00 & 3.33 & 2.00 & 2.78 & 2.67 & 1.33 & 2.00 & 2.00 & 2.00 & 5.00 & 2.67 & 3.22 \\
\hline Plastic & 1.00 & 1.67 & 1.67 & 1.44 & 1.33 & 1.67 & 1.33 & 1.44 & 1.67 & 1.67 & 1.33 & 1.56 & 1.33 & 2.00 & 1.00 & 1.44 & 1.33 & 1.67 & 1.67 & 1.56 \\
\hline Um & 4.33 & 2.00 & 2.67 & 3.00 & 2.67 & 2.33 & 3.67 & 2.89 & 2.00 & 2.67 & 2.33 & 2.33 & 1.67 & 2.00 & 3.00 & 2.22 & 3.00 & 2.33 & 2.33 & 2.56 \\
\hline Mean & 2.60 & 2.87 & 2.13 & & 2.40 & 2.60 & 2.60 & & 2.27 & 2.47 & 2.40 & & 2.40 & 2.00 & 2.27 & & 2.47 & 2.87 & 2.87 & \\
\hline & \multicolumn{4}{|c|}{ LSD (Variety) NS } & \multicolumn{2}{|r|}{ NS } & \multicolumn{3}{|c|}{ NS } & \multicolumn{2}{|l|}{ NS } & \multicolumn{2}{|r|}{ NS } & & & & & & & \\
\hline & \multicolumn{4}{|c|}{ LSD (Mulch) 0.840} & \multicolumn{2}{|r|}{1.062} & \multicolumn{3}{|c|}{ NS } & \multicolumn{2}{|l|}{0.994} & \multicolumn{2}{|r|}{1.199} & & & & & & & \\
\hline & \multicolumn{4}{|c|}{ LSD (Variety x Mulch) } & \multicolumn{2}{|r|}{1.455} & & NS & & \multicolumn{2}{|l|}{ NS } & \multicolumn{2}{|r|}{ NS } & & & & & & & \\
\hline
\end{tabular}

Grass = Dry grass; $\mathrm{G} / \mathrm{N}=$ Groundnut (live mulch); Palm = Dry palm frond; Plastic = Black polythene; UM = Unmulch.

LSD = Least Significant Difference; NS = Not Significant; WAP = Weeks after Planting 
Table 7: Effect of Varieties and Mulch Types on Cotton Leaf Roller (Notarcha derogata) at 2, 3, 4, 5 and 6 WAP

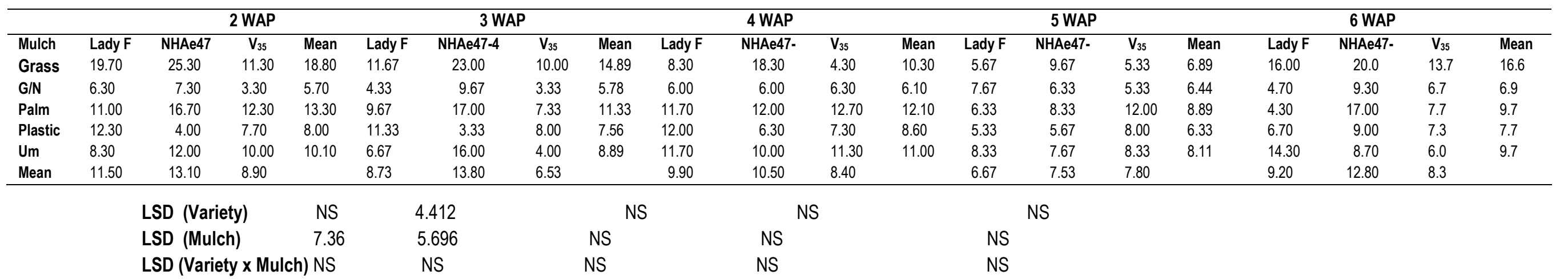

Grass $=$ Dry grass; $\mathrm{G} / \mathrm{N}=$ Groundnut (live mulch); Palm = Dry palm frond; Plastic $=$ Black polythene; UM = Unmulch.

LSD = Least Significant Difference; NS = Not Significant; WAP = Weeks after Planting

Table 8: Effect of Varieties and Mulch Types on Nigerian Grasshopper (Oedaleus nigeriensis) at 2, 3, 4, 5 and 6 WAP

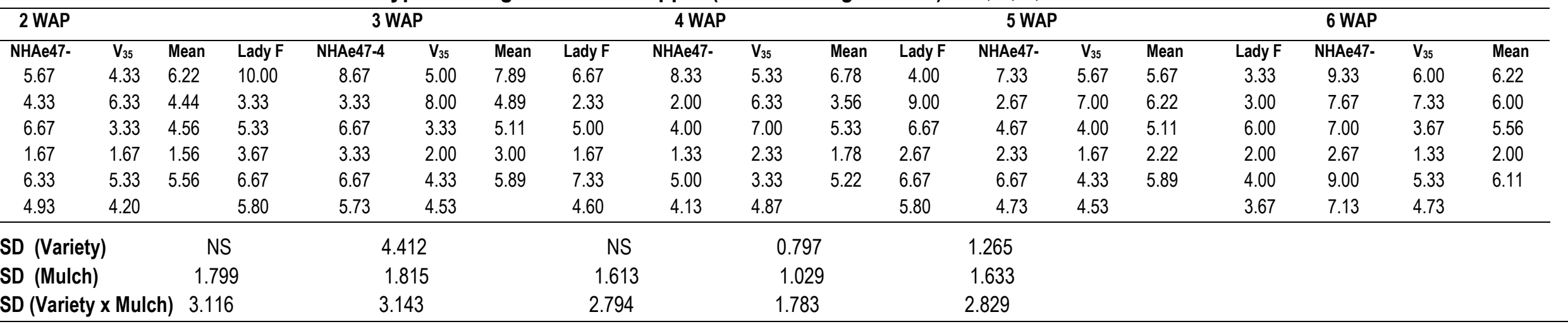

Grass = Dry grass; $\mathrm{G} / \mathrm{N}=$ Groundnut (live mulch); Palm = Dry palm frond; Plastic $=$ Black polythene; UM = Unmulch.

LSD = Least Significant Difference; NS = Not Significant; WAP = Weeks after Planting 
Table 9: Effect of Varieties and Mulch Types on Flea Beetle (Podagrica spp.) at 2, 3, 4, 5 and 6 WAP

\begin{tabular}{|c|c|c|c|c|c|c|c|c|c|c|c|c|c|c|c|c|c|c|c|c|}
\hline & \multicolumn{5}{|c|}{2 WAP } & \multicolumn{2}{|c|}{3 WAP } & \multicolumn{5}{|c|}{4 WAP } & \multicolumn{3}{|c|}{5 WAP } & \multicolumn{5}{|c|}{6 WAP } \\
\hline Mulch & Lady F & NHAe47- & $\mathrm{V}_{35}$ & Mean & Lady F & NHAe47-4 & $\mathrm{V}_{35}$ & Mean & Lady F & NHAe47- & $\mathbf{V}_{35}$ & Mean & Lady F & NHAe47- & $\mathbf{V}_{35}$ & Mean & Lady F & NHAe47- & $V_{35}$ & Mean \\
\hline Grass & 6.00 & 3.00 & 4.33 & 4.44 & 5.67 & 6.33 & 3.33 & 5.11 & 3.00 & 1.33 & 2.67 & 2.33 & 6.67 & 9.33 & 6.00 & 7.33 & 7.33 & 4.33 & 3.33 & 5.00 \\
\hline$G / N$ & 9.33 & 8.33 & 3.00 & 6.89 & 14.33 & 8.33 & 5.67 & 9.44 & 8.00 & 6.67 & 14.33 & 9.67 & 6.33 & 7.00 & 12.00 & 8.44 & 6.00 & 11.00 & 11.00 & 9.33 \\
\hline Palm & 6.33 & 4.00 & 4.00 & 4.78 & 9.00 & 4.00 & 5.33 & 6.11 & 8.67 & 2.33 & 7.67 & 6.22 & 9.33 & 11.33 & 6.00 & 8.89 & 3.33 & 5.67 & 5.33 & 4.78 \\
\hline Plastic & 1.33 & 1.00 & 2.67 & 1.67 & 3.00 & 7.33 & 6.33 & 5.56 & 6.67 & 2.00 & 8.00 & 5.56 & 4.00 & 2.33 & 2.33 & 2.89 & 1.33 & 2.00 & 4.33 & 2.56 \\
\hline Um & 9.67 & 12.00 & 9.00 & 10.22 & 8.67 & 7.00 & 7.33 & 7.67 & 7.00 & 9.33 & 8.67 & 8.33 & 11.67 & 12.00 & 14.67 & 12.78 & 8.67 & 10.33 & 11.33 & 10.11 \\
\hline \multirow[t]{4}{*}{ Mean } & 6.53 & 5.67 & 4.60 & & 8.13 & 6.60 & 5.60 & & 6.67 & 4.33 & 8.27 & & 7.60 & 8.40 & 8.20 & & 5.33 & 6.67 & 7.07 & \\
\hline & \multicolumn{3}{|c|}{ LSD (Variety) } & \multicolumn{2}{|c|}{ NS } & NS & & \multicolumn{5}{|l|}{ NS } & \multicolumn{3}{|l|}{ NS } & & & & & \\
\hline & \multicolumn{3}{|c|}{ LSD (Mulch) } & \multicolumn{2}{|c|}{3.480} & NS & & \multicolumn{2}{|c|}{4.588} & \multicolumn{2}{|c|}{4.231} & & \multicolumn{2}{|c|}{4.630} & & & & & & \\
\hline & \multicolumn{3}{|c|}{.LSD (Variety x Mulch) } & \multicolumn{2}{|c|}{ NS } & NS & & \multicolumn{2}{|c|}{ NS } & \multicolumn{2}{|c|}{ NS } & & \multicolumn{2}{|c|}{ NS } & & & & & & \\
\hline
\end{tabular}

Grass = Dry grass; G/N = Groundnut (live mulch); Palm = Dry palm frond; Plastic = Black polythene; UM = Unmulch.

LSD = Least Significant Difference; NS = Not Significant; WAP = Weeks after Planting 


\section{DISCUSSION}

Throughout the duration of the experiment, application of mulch had significant effect on the number of leaves of okra. In crop production, mulching is one of the most beneficial and simplest agronomic practices used to aid water retention, increase soil nutrition, improve seed germination and seedling survival, suppress weed growth, enhance pest and disease protection, enhance root establishment, transplant survival and overall plant growth performance (Mugalla et al., 1996; Chalker-Scott, 2007; lqbal, et al., 2009; Mochiah et al., 2012). Generally, mulched plants have been shown to have higher shoot dry weight than non-mulched plants (Amoroso et al., 2010).

Of the mulched plots, greater numbers of leaves per plant were recorded in those with plastic mulch. This could be as a result of the retention of nutrients and water that could have been lost through evaporation from the soil surface and almost complete control of weeds in the plots with plastic mulch. Ashrafuzzaman et al., (2011), evaluating the effect of blue, transparent and black plastic mulch and bare soil (as control) on the growth and yield of chilli (Capsicum annuum L.) had earlier reported that the number of leaves, plant height, stem base diameter, number of primary branches and yield were better in the plants on plastic mulch.

Variety had the most pronounced effect on leaf area. NHAe47-4) variety had larger leaf area than $\mathrm{V}_{35}$ and Lady's finger in that order. lyagba et al. (2012) and lyagba and lbe (2013) had also reported an increasing leaf area order of NHAe47-4 $>V_{35}>$ lady's finger. These were corroborated by earlier work of Bavec et al. (2007), who reported that variety had influence on leaf area index (LAl) of winter wheat. Addai and Alimiyawo (2015) also reported the influence of variety on LAl in Sorghum (Sorghum bicolor L. Moench).

The control (unmulch) had the lowest plant height followed by groundnut (live mulch). The effect of cowpea as life-mulch in reducing plant height has been reported by Mochiah et al. (2012) in okra. This could be as result of competition for nutrient, light and space between okra and different weed types in the control and cowpea life-mulch with okra plants on the other hand.

Plastic mulch recorded the lowest number of insect pests at all developmental stages of the crop in the field. The mulch could have offered a barrier against weeds, invariably reducing insect pests that could have used the weeds as secondary hosts. This may have limited insect pest attack which concomitantly reduced leaf damage. Awodoyin et al. (2007), in field trials with plastic (grey-on-black), grass (Pennisetum) and woodchip (Teak) mulches, had noted that the mulches effectively controlled weeds, conserved soil moisture, improved crop growing environment which ultimately increased growth and fruit yield of Tomato (Lycopersicon esculentum Mill.). The fact that leaves are the main organs of photosynthesis implies that greater number of undamaged leaves results in an increase in 
fruit yield, consequent fruit weight and greater dry matter than the control plants (Oyedunmade and Izuogu, 2010 and 2011).

The polyethylene film, fixed over wet soil, could also have trapped solar heat which probably killed or discouraged insect pests from perching (Stapleton, 2000; Warner and Zandstra, 2004). Solarization mimics soil fumigation without using soil fumigants like methyl bromide, kills pests and pathogens in the soil and is regarded as a general biocidal treatment (Anonymous, 2018).

Certain light wavelengths are reflected into the sky by plastic mulch that deters flying insects such as whiteflies and aphids from landing on the plants (Csizinszky et al.,1999; Nardozzi, 2018). Also, the all-black background could have provided a visually unattractive stimuli that discouraged insects from visiting the black polyethylene covered plots. It has been suggested that the light reflection from reflective plastics repels and confuses insect pests which often may have better controlling effect than insecticides (Summers et al., 2004).

Reflective mulches has been reported to consistently had fewer numbers of adult whiteflies and aphids compared with the standard white mulch treatments (Summers et al., 2004) and is currently being suggested as an alternative to conventional pesticides in suppressing whitefly and aphid activities in selected vegetable crops (Schalk et al., 1979; Summers et al., 2004).

The reported incidence of blister beetle (Mylabris pustulatus), flea beetle (Podagrica spp.) and cotton leaf roller (Notarcha derogata) as the most predominant insect pests at the vegetative and early flowering stages of development agrees with earlier works of Adhikary (1984) and Obeng-Ofori and Sackey (2003) who also recorded these insects as the major insect pests of okra in Togo and Ghana, respectively. Podagrica spp. and other defoliators perforate the leaves reducing photosynthetic area which may predispose the plant to pathogenic attack (Balogun.and Babatola, 1999).

Though cowpea live mulch has been reported to have effectively suppressed insect pest populations of pepper (Mochiah et al., 2012), the use of groundnut live mulch in this study did not reduce insect pest population on okra. Dry grass also did not suppress insect pest population. It has been earlier reported (Johnson et al., 2004) that pest populations in watermelons and potatoes plots were relatively higher when mulched with straw compared to other mulch treatments. 


\section{CONCLUSION}

There were no clear cut differences in the performance of the three okra varieties under the parameters tested as variety alone had no significant effect on insect pest infestation throughout the duration of the study.

Results from the five different mulch types evaluated showed that plots treated with plastic mulch recorded the least number of damaged leaves, which suggests increased photosynthetic ability of the plants that may lead to better yield. The use of palm frond, grass and life mulch are not advisable when insect pest control is targeted.

Five insect pest types: Dysdercus spp., Bemisia tabaci, Notarcha derogata, Oedaleus nigeriensis and Podagrica spp. were identified as the major vegetative insect pests of Abelmoschus esculentus in the humid tropical environment of Owerri, Imo State, Nigeria.

For maximum crop performance and control of insect pests of Abelmoschus esculentus, plastic mulch is recommended. This recommendation, however, should be for high value crops because plastic mulch may be unaffordable for resource poor farmers. 


\section{REFERENCES}

Addai, I. K. and Alimiyawo, M. (2015). Graphical determination of leaf area index and its relationship with growth and yield parameters of Sorghum (Sorghum bicolor L. Moench) as affected by fertilizer application. Journal of Agronomy 14 (4): 272-278.

Adhikary, S. (1984). Results of field trials to control common insect pests of okra, Hibiscus esculentus L., in Togo by application of crude methanolic extracts of leaves and seed kernels of the neem tree, Azadirachta indica A. Juss. Journal of Applied Entomology 98(1-5): 327-331.

Ahmed, B. I., Yusuf, S. R., Yusuf, A. U., Aliyu, M. (2007). Comparative efficacy of different concentrations of some promising insecticides for the control of Podagrica spp. (Coleoptera: Chrysomelidae) on okra Abelmoschus esculentus (L.) Moench. Global Journal of Agricultural Science 6:31-34

Ahukaemere, C. M., Onweremadu, E. U., Ndukwu, B. N and Nkwopara, U. N. (2016). Properties of soils of contrasting lithosequences in south-eastern Nigeria. FUTO Journal Series (FUTOJNLS) 2(1): 48 56

Alegbejo, M., Ogunlana, M. and Banwo, O. (2008).Short communication. Survey for incidence of Okra mosaic virus in northern Nigeria and evidence for its transmission by beetles. Spanish Journal of Agricultural Research 6(3): 408-411.

Al-Rawahy, S. A., Al-Dhuhli, H. S., Prathapar, S.A. and AbdelRahman, H. (2011). Mulching material impact on yield, soil moisture and salinity in saline-irrigated sorghum plots. International Journal of Agricultural Research 6: 75-81. 
Amoroso, G., Frangi, P., Piatti, R., Fini, A. and Ferrini, F. (2010). Effect of mulching on plant and weed growth, substrate water content, and temperature in container-grown Giant Arborvitae.Horticultural Technology 20 (6): 957- 962

Anonymous (2018). Soil Solarization: How to kill soil pests and diseases. Plant Care Today. https://plantcaretoday.com/soil-solarization.html

Ashrafuzzaman, M., Abdul Halim, M., Ismaill, M.R., Shahidullahll, S.M. and Alamgir Hossainl, M.A. (2011). Effect of plastic mulch on growth and yield of chilli (Capsicum annuum L.).Brazilian Archives of Biology and Technology 54(2): 321-330.

Awodoyin, R. O., Ogbeide, F. I. and Oluwole, O. (2007). Effects of three mulch types on the growth and yield of tomato (Lycopersicon esculentum Mill.) and weed suppression in Ibadan, Rainforestsavanna transition zone of Nigeria. Tropical Agricultural Research and Extension 10: 54-60.

Babatola, L. A. and Olaniyi J. O. (1999). Effect of some management practices on the performance of tomato (Lycopersicon esculentum Mill). Agrosearch 5(1\&2): 56-61

Balogun, O. S. and Babatola, J. O. (1999). Effect of plant age and injury on the pathogenicity of Choanephora cucurbitarum in okra Abelmoschus esculentus Moench. .Agrosearch 5(1\&2): 62-69.

Ban, D., Zanic, K., Dumicic, G., Culjak, T.G. and Ban, S.G. (2009). The type of polyethylene mulch impacts vegetative growth, yield and aphid populations in watermelon production. Journal of Food Agriculture and Environment 7: 543-550.

Bavec, M., Vuković, K., GrobelnikMlakar, S., Rozman, C. and Bavec, F. (2007). Leaf area index in winter wheat: response on seed rate and nitrogen application by different varieties. Journal of Central European Agriculture 8(3): 337- 342

Berihun, B. (2011). Effect of mulching and amount of water on the yield of tomato under drip irrigation. Journal of Horticulture Science and Forestry 3: 200-206

Chalker-Scott, L. (2007). Impact of mulches on landscape plants and the environment - A review. Journal of Environmental Horticulture 25(4): 239- 249.

Csizinszky, A. A., Schuster, D. J.and Polston, J. E. (1999). Effect of ultraviolet- reflective mulches on tomato yields and on the silverleaf whitefly. Horticultural Science 34(5): 911-914

Dabiré-Binso, C. L., Malick, N., Ba, K. S. and Antoine, S. (2009). Preliminary studies on incidence of insect pest on okra, Abelmoschus esculentus (L.) Moench in central Burkina Faso. African Journal of Agricultural Research 4(12):1488-1492.

Gilreath, P. (2001). Cultural Controls: Mulches. Integrated Pest Management,. 173-186. In: Integrated Pest Management for Floriculture and Nurseries (2001), Publication 3402, University of Florida, 422 pages. $\quad$ http://ipm.ifas.ufl.edu/resources/success_stories/T\&PGuide/pdfs/Chapter7/Chapter7Cultural_controls.pdf 
Hatami, S., Nourjou, A., Henareh, M. and Pourakbar, L. (2012). Comparison effects of different methods of black plastic mulching and planting patterns on weed control, water-use efficiency and yield in tomato crops. International Journal of Agricultural Science 2: 928-934.

Ibeawuchi, I. I., Obiefuna J. C. and Ofoh M. C. (2005). Effects of row spacing on yield and yield components of Okra (Abelmoschus esculentus) and mixture groundnut (Archis hypogaea). Journal of Agronomy 4(4): 304-307.

Iqbal, Q., Amjad, M., Asi, M. R and Ali, M. A. (2009). Vegetative and reproductive evaluation of okra under different plastic mulches. Pakistanian Journal of Agricultural Science 46: 113-118.

Iremiren G. O. and Okiy, D. A. (1986). Effect of sowing dates on the growth, yield and quality of okra in Southern Nigeria. Journal of Agricultural Science 106: (1): 21-26

lyagba, A. G., Onuegbu, B. A. and Ibe, A. E. (2012). Growth and yield response of okra (Abelmoschus esculentus (L.) Moench) varieties to weed interference in southeastern Nigeria. Global Journal of Science Frontier Research in Agriculture and Veterinary Sciences 12(7), Version 1.0: 22-31.

lyagba, A. G. and Ibe, A. E. (2013). Influence of weed interference duration on the yield and viscosity of okra (Abelmoschus esculentus (L) Moench) varieties in south-eastern Nigeria. ARPN Journal of Agricultural and Biological Science 8(12): 793 - 799.

Jamil, M., Munir, M., Qasim, M., Baloch, J. and Rehman, K. (2005). Effect of different types of mulches and their duration on the growth and yield of Garlic (Allium sativum L.). International Journal of Agriculture and Biology 7(4): 588 - 591.

Johnson, J. M., Hough-Goldstein, J. A. and Vangessel, M. J. (2004). Effects of straw mulch on pest insects, predators and weeds in watermelons and potatoes. Entomological Society of America, Lanham 33(6): 1632-1643.

Judd, W. S., Campbell, C. S., Kellogg, E. A., Stevens P. F. and Donoghue, M. J. (2015). Plant Systematics: A Phylogenetic Approach (Fourth Ed.). Sinauer Associates, Inc Publishers. Sunderland, Massachusetts USA; 677 pages.

Kedar,S. C., Kumaranag, K. M., Bhujbal, D. S. and Thodsare, N. H. (2014). Insect pests of okra and their management. Popular Kheti 2(3): 112-119

Kwabiah, A. B. (2004). Growth and yield of sweet corn (Zea mays L.) cultivars in response to planting date and plastic mulch in a short-season environment. Scientia Horticulturae102: 147-166.

Mahadeen, A. Y. (2014). Effect of polyethylene black plastic mulch on growth and yield of two Summer vegetable crops under rain-fed conditions under semi-arid region conditions. American Journal of Agricultural and Biological Sciences 9(2): 202-207

Mochiah, M. B., Baidoo, P. K. and Acheampong, G. (2012). Effects of mulching materials on agronomic characteristics, pests of pepper (Capsicum annuum L.) and their natural enemies population. Agriculture and Biology Journal of North America 3(6): 253-261 
Mugalla, C. I., Jolly, C. M. and Martin, N. R. (1996). Profitability of black plastic mulch for limited resource farmers. Journal of Production Agriculture 9: 283-288.

Nardozzi, C. (2018). Plastic Mulch Repels Pests. National Gardening Association https://garden.org/learn/articles/view/2440/

NIHORT. (1986). National Horticultural Research Institute. Advances in Fruit and Vegetable Research at NIHORT (1976-1986): A Commemorative Publication to Mark the 10th Anniversary of the National Horticultural Research Institute (NIHORT), Ibadan. NIHORT Press, Ibadan, Nigeria.

NIMET. 2012. Nigerian Meteorological Agency, Nigeria. Annual Climate Review Bulletin, 2012. http://www.nimet.gov.ng/annual-climate-review

NRC (National Research Council) (2006). Okra: Lost Crops of Africa: Volume II: Vegetables. The National Academies Press. Washington D.C. 20001. Chapter 16: 286 - 301. https://doi.org/10.17226/11763

Obeng-Ofori, D and Sackey, J. (2003). Field evaluation of non-synthetic insecticides for the management of insect pests of okra Abelmoschus esculentus (L.) Moench in Ghana. Ethiopian Journal of Science 26:145-150

Odebiyi, J. A. (1980). Relative abundance and seasonal occurrence of Podagrica spp. (Coleoptera: Chrysomelidae) on okra in Southwestern Nigeria. African Journal of Agricultural Science 6: 83-84.

Oyedunmade, E. E. A. and Izuogu, N. B. (2010 \& 2011). Efficacy of aqueous extract of lemon Grass (Andropogon citratus L.) against root-knot nematode pests of okra (Abelmoschus esculentus (L.) Moench). Agrosearch 11(1\&2): $31-38$

Pitan, O. and Ernest-Ekoja, E. (2011). Yield response of okra, Abelmoschus esculentus (L.) Moench to leaf damage by the flea beetle, Podagrica uniforma Jacoby (Coleoptera: Chrysomelidae). Crop Protection 30(10):1346-1350.

Sabitha, V., Ramachandran, S., Naveen, K. R., and Panneerselvam, K. (2012). Investigation of in vivo antioxidant property of Abelmoschus esculentus (L) Moench.fruit seed and peel powders in streptozotocin-induced diabetic rats. Journal of Ayurveda and Integrative Medicine 3(4): 188-193.

Sathish, D. K., Eswar, D. T., Praveen, A. K., Ashok, K. K., Bramha, D. S., Srinivasa, R. and Ramarao, N. (2013).A review on Abelmoschus esculentus (Okra). International Research Journal of Pharmaceutical and Applied Sciences 3(4):129 - 132

Schalk, J. M.; Creighton, C. S.; Fery, R. L.; Sitterly, W. R.; Davis, B. W.; McFadden, T. L. and Day, A. (1979). Reflective film mulches influences insect control and yield in vegetables. Journal of American Society of Horticultural Science 104(6): 759-762.

Schippers, R. R. (2000). African indigenous vegetables. An overview of the cultivated species. Chatham, UK: Natural Resources Institute/ACP-EU Technical Centre for Agricultural and Rural Cooperation; University of Greenwich. London. United Kingdom. 223 pp. 
Stapleton, J. J. (2000). Soil solarization in various agricultural production systems. Crop Protection 19: 837841.

Summers, C. G., Mitchell, J. P. and Stapleton, J. J. (2004). Management of aphid-borne viruses and Bemisia argentifolii (Homoptera: Aleyrodidae) in zucchini squash by using UV reflective plastic and wheat straw mulches. Environmental Entomology 33: 1447-1457.

Vanlommel, S., Duchateau, L. and Coosemans, J. (1996). The effect of okra mosaic virus and beetle damage on yield of four okra cultivars. African Crop Science Journal; 4: 71- 77.

Wahua, T. A. T. (1999). Applied Statistics for Scientitic Studies. Africa-Link Press, Ibadan Nigeria. Pp: 108248.

Warner, J. and Zandstra, J. (2004).Biodegradable polymer mulches in bell pepper production. Pages 1-5 https://www.ridgetownc.com/research/documents/zandstra_pepper_degradable_mulch_harrow_04. PDF 